DE

M E D I C I N A

T R O P I C A L

$\mathrm{DE}$

SÃO PAULO

JOURNAL OF THE SÃO PAULO INSTITUTE OF TROPICAL MEDICINE

Universidade Federal de Campina Grande Centro de Educação e Saúde, Unidade Acadêmica de Saúde, Programa de Pós-Graduação em Ciências Naturais e Biotecnologia, Campus Cuité, Paraíba, Brazil

Correspondence to: Renner de Souza Leite

Universidade Federal de Campina Grande, Centro de Educação e Saúde, Unidade Acadêmica de Saúde, Olho D’água da Bica s/n, CEP 58175-000, Cuité, PB, Brazil

Tel: $+550833372-1900$

E-mail: rennerleite @yahoo.com.br

Received: 17 January 2017

Accepted: 31 March 2017

\section{The epidemiology of snakebite in the Rio Grande do Norte State, Northeastern Brazil}

\author{
Aluska Vieira Tavares, Kaliany Adja Medeiros de Araújo, Michael Radan de \\ Vasconcelos Marques, Alecxandro Alves Vieira, Renner de Souza Leite
}

\section{ABSTRACT}

This report is a retrospective study of the epidemiology of snakebite cases recorded from 2007 to 2014 in the Rio Grande do Norte State, northeastern Brazil. Data was collected from the Injury Notification Information System database of the Health Department of Rio Grande do Norte. A total of 3,019 cases were studied. Cases were distributed over all months of the period studied and occurred mainly in rural areas. Snakes of the genus Bothrops, Crotalus, Micrurus, Lachesis and non-venomous snakes were responsible for 1,507, 185, 52, 6 and 673 cases, respectively. Snakebites predominated in males with age between 10 and 29 years old. Most victims were bitten on the feet and received medical assistance within 1-3 $\mathrm{h}$ after being bitten. Cases were mostly classified as mild and progressed to cure. Envenomation by snakebite in Rio Grande do Norte is an environmental public health problem that needs to be monitored and controlled throughout the year. Additionally, the training of health professionals is urgent in order to improve the registration of epidemiological information and medical care to victims.

KEYWORDS: Envenomation. Public health. Snakebite.

\section{INTRODUCTION}

Snakebite envenomation is a neglected public health problem, particularly in tropical and subtropical countries, due to its high morbidity and potential lethality ${ }^{1}$. This injury has affected mainly agricultural workers and their children in some of the most impoverished rural areas of developing countries in Africa, Asia, Latin America and Oceania ${ }^{2}$. It has been estimated that the annual load of snakebite worldwide is above two million cases, causing more than 100,000 deaths and leaving about 400,000 people with permanent sequela ${ }^{3}$. Despite these alarming numbers, questions related to epidemiological research, access to treatment and training of health workers have been largely left out of national public policies ${ }^{2,3}$.

In 1986, Brazilian Health Ministry implemented the National Program for Snakebites Control. This program made mandatory the records by health providers of epidemiological and clinical data of the snakebite cases ${ }^{4}$. Since then, the number of cases reported in Brazil has significantly increased in all regions of country. There has been a meaningful increase in reporting in the last years, rising from 11,479 in 2000 to 24,467 in 2015 , totalizing 416,109 cases $^{5}$. The number of deaths by snakebite also increased, from 57 in 2000 to 107 in 2015 , totalizing 1,720 deaths $^{6}$. However, there is a considerable variation in the incidence of the snakebite cases among the regions, with highest incidence in the North followed by the Midwest, Northeast, South and Southeast regions ${ }^{7}$. 
These values are expected to be higher due likely to failures in data collection and underreporting of the cases $^{8}$. In Brazil, snakebite cases predominately occur in rural areas during the hot and rainy months, and typically affect 15-49-year-old male rural workers, who are mainly bitten on the foot or hand 9 . Snakes of the genus Bothrops (Viperidae) are known to be responsible for the majority of snakebite cases, bites by Crotalus (Viperidae) are less frequent, and bites by Lachesis (Viperidae) and Micrurus (Elapidae) are rare ${ }^{9}$. Bites from non-venomous snakes can also induce injury, often due to lacerations caused by the snake's teeth or from a resulting infection ${ }^{10}$. Rural areas have showed higher morbidity and mortality rates. This may be due to higher exposure of the rural population to risk areas and to difficulties in accessing health centers that can provide snake antivenom ${ }^{3,9}$. Many victims suffer permanent consequences due to the necrotic action of venoms. And there are also psychological consequences. The economic impact of these incidents is considerable, because most victims are young workers ${ }^{2,3}$.

The information regarding the incidence of snakebite cases and lethality rate per region, as well as the epidemiological and clinical data of the envenomation are essential for developing public policies aimed at reducing the number of incidents, and improving medical care of the victims ${ }^{11}$. Despite of the medical importance of snakebite envenomation, the epidemiological characteristics of the cases in Northeastern Brazil are not conclusively determined. In addition, social and environmental changes occurring in this region during recent decades indicate that new research is needed regarding this topic. To address this shortcoming, the current study analyzed epidemiological data of the snakebite cases recorded between 2007 and 2014 in the Rio Grande do Norte State, Northeastern Brazil.

\section{MATERIALS AND METHODS}

\section{Study area}

The Rio Grande do Norte State, whose capital is Natal, is a federal unit that integrates the Northeastern region of Brazil. It is composed of 167 municipalities, covering an area of 52,811.126 km². These municipalities are distributed in four regions: Oeste Potiguar, Central Potiguar, Agreste Potiguar and Leste Potiguar. The total resident population of state is 3,168,027 inhabitants, with 2,464,991 living in urban areas and 703,036 in rural areas ${ }^{12}$. The population density is 60 inhabitants $/ \mathrm{km}^{2}$. Regarding gender, its population consists about 1,548,887 men and 1,619,140 women ${ }^{12}$. In Rio Grande do Norte there are two climate types: tropical and semiarid. The first takes place on the east coast, with more abundant rainfall, while the latter dominates almost all areas of the state, including the north coast. In region of semiarid climate, rainfall is scarce and irregular $^{13}$. The majority of the territory of the Rio Grande do Norte is located within the "Drought Polygon", an area that is affected annually by prolonged periods of drought. Almost the entire region has a low rainfall rate, high average temperatures, acute water deficits, generally thin and often salty soils, and caatinga vegetation ${ }^{13}$. The average annual temperature in the state is $26^{\circ} \mathrm{C}$, with maximum temperature of $31{ }^{\circ} \mathrm{C}$ and minimum of $21{ }^{\circ} \mathrm{C}^{13}$. The rainy season occurs between the months of April to July and rainfall is below $600 \mathrm{~mm}$ annually ${ }^{14}$.

\section{Data collection}

Snakebite cases are mandatorily recorded by the National System of Notifiable Diseases [Sistema Nacional de Agravos de Notificação (SINAN)] based on medical records used in the investigation and follow-up of cases of injury by venomous animals. The SINAN is a national electronic surveillance system that contains a variety of diseases in an integrated database that also includes snakebite cases ${ }^{4}$. All snakebite cases in the Rio Grande do Norte State recorded to SINAN from 2007 to 2014 were included in current study. Demographic and population data from the Brazilian Institute of Geography and Statistics were used to calculate the incidence rates for snakebite cases.

\section{Spatial distribution}

The map was prepared with the QGIS 2.8 software, using estimates of the average incidence by municipality. The incidence rate was calculated as the ratio of cases by the population of each municipality, estimated for every 100,000 inhabitants. Spatial interpolation of the incidence of snakebite cases was mapped using data from 167 municipalities and performed by the Inverse Distance Weight method ${ }^{15}$.

\section{Statistical analysis}

Statistical analyses were performed using the Chi-square (Likelihood Ratio Chi-Square) test and Correspondence Analysis (ANACOR), Mann-Whiney and Kruskal-Wallis and Odds Ratio tests. The level of significance was $p<0.05$. All statistical analyses were performed using the software SPSS ${ }^{\circledR}$ version 22.0 (Statistical Package for Social Sciences) for Windows. 


\section{Ethical clearance}

This study was approved by the Ethics Research Committee of the Federal University of Campina Grande (Protocol $\mathrm{N}^{\circ}$ 1357.708/2015) and followed the guidelines established by the Declaration of Helsinki.

\section{RESULTS}

According to the SINAN, 3,019 snakebite cases were recorded in the Rio Grande do Norte State from January/2007 to December/2014, resulting in an average incidence rate of 12.0 cases $/ 100,000$ inhabitants/year. Incidence was higher in 2010 (19.6 cases/100,000 inhabitants) and 2009 (15.6 cases/100,000 inhabitants), and lower in 2013 ( 7.4 cases/100,000 inhabitants) and 2014 (7.8 cases $/ 100,000$ inhabitants). Figure 1 shows that snakebite cases were recorded in all months of the years studied, with higher frequencies in July $(n=320 ; 10.6 \%)$, June $(n=307$; $10.2 \%$ ) and August ( $\mathrm{n}=298 ; 9.8 \%)$. Lower frequencies were recorded in December $(\mathrm{n}=186 ; 6.2 \%)$, November $(\mathrm{n}=188$; $6.2 \%)$ and January $(\mathrm{n}=210 ; 6.9 \%)$. Figure 2 shows that cases were recorded in 163 municipalities. Incidence rates were unevenly distributed across the Rio Grande do Norte State, with values between 0 and 1,106 cases/100,000 inhabitants. Mapping showed a large area with high incidence rates in the state, especially among regions of Agreste Potiguar and Central Potiguar. The highest incidence rates, those between 884.8 and 1,106.0 cases/100,000 inhabitants, were reported in the following municipalities: Monte das Gameleiras, Barcelona, Triunfo Potiguar, Caiçara do Rio dos Ventos, Ruy Barbosa, Sítio Novo, Lajes Pintadas, Pedra Preta, Pedro Avelino, Santana do Matos, Taboleiro Grande, São Bento do Trairi, Tibau, São Bento do Norte, Japi and Coronel Ezequiel. Table 1 shows that most of the cases affected males $(n=2,304 ; 76.3 \%)$. Regarding the area of occurrence, $63.3 \%$ cases were reported in rural areas. The most of cases affected age group was between 10 and 19 years old $(\mathrm{n}=537 ; 17.8 \%)$, followed by 20 and 29 years $(\mathrm{n}=505 ; 16.7 \%)$. The area of the body bitten most often was the feet $(n=1,333 ; 44.1 \%)$. Regarding the time elapsed between the snakebite and medical assistance, 930 (30.8\%) cases were attended within 1 to $3 \mathrm{~h}$ after being bitten, 717 $(23.7 \%)$ cases within the first hour, and $533(17,6 \%)$ cases within 3 to $6 \mathrm{~h}$ after being bitten. A total of 1,750 (58\%) victims were envenomed. Snakes of the genus Bothrops were responsible for 1,507 (49.9\%) cases, Crotalus for 185 (6.1\%) cases, Micrurus for 52 (1.7\%) cases, Lachesis for 6 $(0.2 \%)$ cases, and non-venomous snakes for 673 (22.3\%) cases. The laboratory test to assess the blood coagulation time was conducted in 1,676 patients. The blood-clotting time was normal in $694(23 \%)$ patients ( $<10$ minutes), whereas $982(32.5 \%)$ patients showed abnormal blood clotting time (from 10 to 30 minutes). Table 2 shows the severity and progression of the cases for each snake genus. Of the 1,507 snakebite cases caused by Bothrops, 760 $(50.4 \%)$ were classified as mild, $468(31.1 \%)$ as moderate and $61(4 \%)$ as severe. Of the 185 cases of envenomation by Crotalus, $84(45.4 \%)$ were classified as mild, 71(38.4\%) as moderate and $11(5.9 \%)$ as severe. A total of 52 snakebite cases involving Micrurus were recorded, with 21 cases (40.4\%) classified as mild, $11(21.2 \%)$ as moderate and $13(25 \%)$ as severe. Of the 6 cases caused by Lachesis, 4 (66.7\%) were classified as mild, $1(16.7 \%)$ as moderate and $1(16.7 \%)$ as severe. 673 cases were caused by snake non venomous, with $658(97.8 \%)$ cases classified as mild, $8(1.2 \%)$ as moderate and $1(0.1 \%)$ as severe. Most of the cases progressed to cure $(\mathrm{n}=2,471 ; 81.8 \%)$, and 13 deaths were reported in the study period, resulting in a lethality rate of $0.43 \%$.

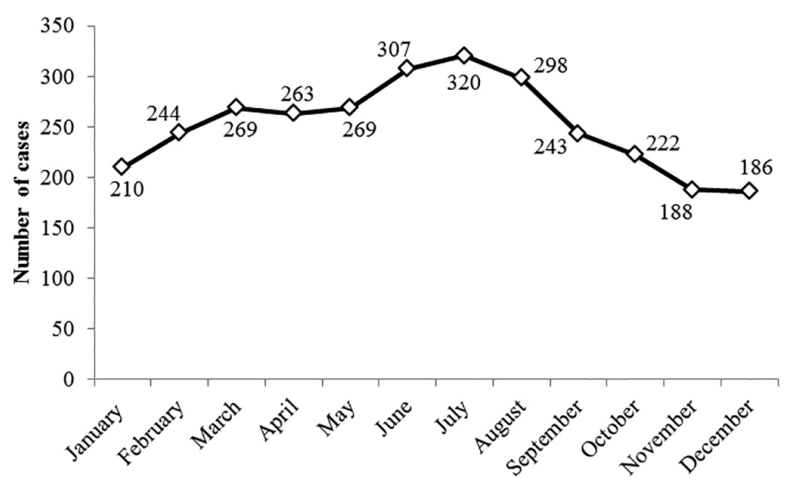

Figure 1 - Distribution by month of snakebite cases in the Rio Grande do Norte, Brazil, from 2007 to 2014.

\section{DISCUSSION}

The incidence of snakebites, regardless of the species involved, varies from country to country and among regions in a country, depending on factors such as climate, ecological parameters, biodiversity, the distribution of venomous snakes, human population density, economic activities, and types of dwellings, among others ${ }^{16}$. The region studied includes compounded risk factors for exposure to snakebites as a result of its high average temperatures and high number individuals living in rural areas. Moreover, increased environmental degradation may contribute to the development of desertification processes and, consequently, to the reduction of natural habitat for snakes. In current study, envenomation by snakebites was recorded in 163 municipalities, indicating that these cases have large spatial distribution. Higher incidences take 


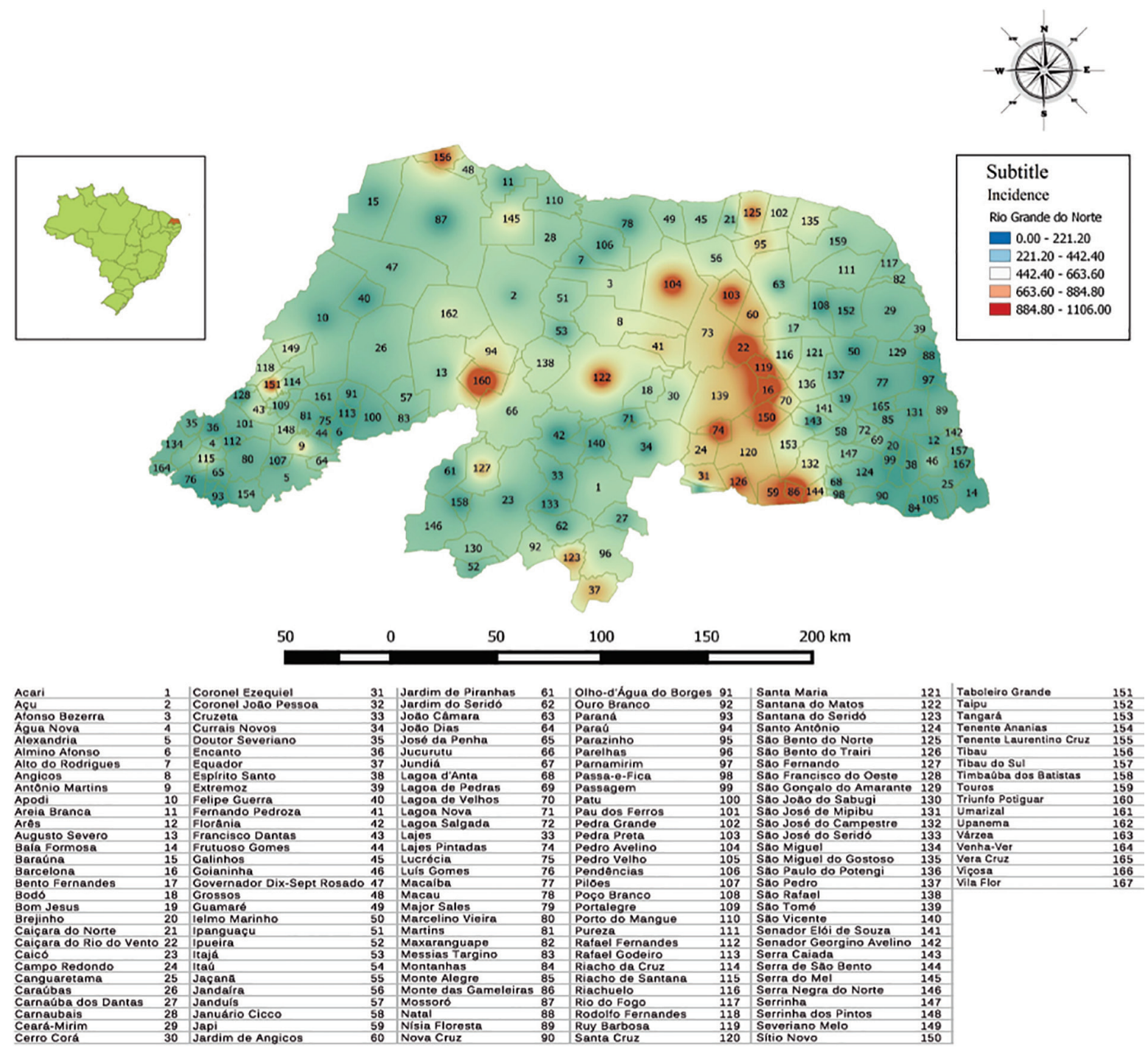

Figure 2 - Distribution by incidence of snakebite cases in the Rio Grande do Norte, Brazil, from 2007 to 2014.

place in municipalities located in the Agreste Potiguar and Central Potiguar regions, mainly in the Angicos and Borborema Potiguar microregions. The semiarid climate is predominant in these regions of the state, extending from the East to the West coast. The arid climate is also present in the Central area as well as in the North coast, extending almost continuously in a narrow strip until the extreme south of the state ${ }^{17}$. The Angicos micro-region has a population of 51,304 inhabitants ${ }^{12}$ and stands out in the Central Potiguar mesoregion for its goat farming activity. The agricultural scenario is diversified with the production of cotton, cashew nuts, manioc, grains (corn, beans and sorghum) and fruits (banana, mango and melon) ${ }^{18}$. The Borborema Potiguar microregion has a population of 134,027 inhabitants $^{12}$ notable in the Agreste mesoregion for its agricultural activity, mainly goat farming and the cultivation of: cotton, cashew nuts, sisal or agave, manioc, grains (corn and beans) and fruits (mango and passion fruit) ${ }^{18,19}$. The high incidence of snakebite accidents in these microregions of Rio Grande do Norte may be the result of the large number of individuals who work in pastoral activities. These activities favor the encounter of these individuals with snakes, increasing the possibility of accidents. In an investigation carried out in Tanzania, Kipanyula and Kimaro ${ }^{20}$ reported that livestock grazing and agriculture are the main economic activities associated with snakebite accident cases.

According to the Ministry of Health, snakebite accidents in Brazil are susceptible to seasonal factors, with a predominance of cases during the hot and rainy months ${ }^{21}$. According to the Ministry of Health and Swarrop and $\mathrm{Grab}^{22}$, snakebites indices reflects a significant regional variation. As a result, regionalized studies may evidence considerable differences such as the ones between the South/Southeast and the Northeast region. The epidemiological studies realized in 
Table 1 - Epidemiological characteristics of snakebite cases in the State of Rio Grande do Norte, Brazil, from 2007 to 2014

\begin{tabular}{|c|c|c|}
\hline Variables & $\begin{array}{c}\text { Number of } \\
\text { Cases }\end{array}$ & $\%$ \\
\hline \multicolumn{3}{|l|}{ Gender } \\
\hline Male & 2,304 & 76.3 \\
\hline Female & 715 & 23.7 \\
\hline \multicolumn{3}{|c|}{ Geographical location of the case } \\
\hline Urban & 852 & 28.2 \\
\hline Rural & 1,910 & 63.3 \\
\hline Periurban & 76 & 2.5 \\
\hline Unknown & 181 & 6 \\
\hline \multicolumn{3}{|l|}{ Victim's age (years) } \\
\hline $0|-| 9$ & 266 & 8.8 \\
\hline $10|-| 19$ & 537 & 17.8 \\
\hline $20|-| 29$ & 505 & 16.7 \\
\hline $30|-| 39$ & 490 & 16.2 \\
\hline $40|-| 49$ & 468 & 15.5 \\
\hline $50|-| 59$ & 373 & 12.4 \\
\hline $60|-| 69$ & 238 & 7.8 \\
\hline $70|-| 79$ & 96 & 3.2 \\
\hline $80|-| 109$ & 46 & 1.5 \\
\hline \multicolumn{3}{|l|}{ Affected part of the body } \\
\hline Foot & 1,333 & 44.1 \\
\hline Hand & 372 & 12.3 \\
\hline Toe & 369 & 12.2 \\
\hline Finger & 306 & 10.1 \\
\hline Leg & 240 & 7.9 \\
\hline Arm & 52 & 1.7 \\
\hline Forearm & 29 & 0.9 \\
\hline Trunk & 27 & 0.9 \\
\hline Head & 23 & 0.8 \\
\hline Thigh & 16 & 0.5 \\
\hline Unknown & 252 & 8.3 \\
\hline \multicolumn{3}{|c|}{ Time from bite until assistance (h) } \\
\hline $0-1 \mathrm{~h}$ & 717 & 23.7 \\
\hline $1-3 h$ & 930 & 30.8 \\
\hline $3-6 h$ & 533 & 17.6 \\
\hline $6-12 h$ & 163 & 5.4 \\
\hline $12-24 h$ & 123 & 4.1 \\
\hline$>24 h$ & 135 & 4.5 \\
\hline Unknown & 418 & 13.8 \\
\hline \multicolumn{3}{|l|}{ Coagulation time } \\
\hline Normal & 694 & 23.0 \\
\hline Altered & 982 & 32.5 \\
\hline Test not done & 1,343 & 44.5 \\
\hline \multicolumn{3}{|l|}{ Snake genus } \\
\hline Bothrops & 1,507 & 49.9 \\
\hline Crotalus & 185 & 6.1 \\
\hline Micrurus & 52 & 1.7 \\
\hline Lachesis & 6 & 0.2 \\
\hline Non-venomous snakes & 673 & 22.3 \\
\hline Unknown & 596 & 19.7 \\
\hline
\end{tabular}

the South and Southeast regions have shown that the accidents predominantly occur between the months of October and April, a period of greater rainfall and temperature ${ }^{9,23,24}$. In the Northeast region there is a predominance of cases between the months of February and June, a period coinciding with the region's rainy season ${ }^{25,26}$. In addition, the elevated number of accidents during the rainy period possibly derives from the increase in human activity in the fields, given that the preparation of the soil, plantation and harvest take place during this time ${ }^{27}$. In the present study, cases were recorded in all months of the investigated years, with a higher frequency between the months of May and August - a period which presents the highest pluviometric indices in the investigated region ${ }^{14}$. This finding suggests that the frequency of snakebite accidents is influenced by seasonal factors. The increase in snakebite cases during the months of higher rainfall was also observed in other areas of the Northeast of Brazil ${ }^{14,25,28}$ as well as in epidemiological studies conducted in other regions of the world $29-31$.

Envenomation by snakebite mainly involved men, residents of rural areas, aging between 10 and 19 years of age. Similar results were described by Oliveira et $a l .^{32}$ in a study realized in the state of Paraíba. The predominance of male individuals involved in the accidents may be explained by the large proportion of men undertaking activities which expose them to accidents such as agricultural and extractive activities $^{33,34}$. The relative risk of death among men was 1.01 times higher than among women, probably due to the larger exposure of these individuals to situations and areas of risk. The higher number of cases with individuals of rural areas probably derives from the greater probability of an encounter between the rural population and snakes, and given that rural areas constitute the natural habitat of these animals. In the present study, it was also observed that $76.9 \%$ of deaths occurred among rural inhabitants, showing that this group is not only more exposed to these injuries but also present higher relative risk of death $(R R=1.2)$. The elevated number of envenomations in individuals aging from 10 to 19 years old could be due to the greater participation of people in this age group in field work, contributing to their family income ${ }^{35}$. Although individuals aging from 0 to 9 and 80 to 109 represent a lower percentage in the total of cases, they represent higher risk of death in relation to other age groups, 3.5 and 5.1, respectively. Studies undertaken in other regions of the Northeast of Brazil corroborate with data showing the elderly population at greater risk of death due to snakebites ${ }^{28}$. White ${ }^{36}$ and Avila-Aguero et $a l .{ }^{37}$ considered in their results that accidents involving children present a greater risk of complications and fatality due to their lower body volume in relation to the quantity of venom injected. 
Table 2 - Severity and progression of snakebite cases in the state of Rio Grande do Norte, Brazil, acording to the snake genus, from 2007 to 2014

\begin{tabular}{|c|c|c|c|c|c|c|c|c|c|c|c|c|}
\hline & \multicolumn{12}{|c|}{ Snake genus } \\
\hline & \multicolumn{2}{|c|}{ Bothrops } & \multicolumn{2}{|c|}{ Crotalus } & \multicolumn{2}{|c|}{ Micrurus } & \multicolumn{2}{|c|}{ Lachesis } & \multicolumn{2}{|c|}{$\begin{array}{l}\text { Non-venomous } \\
\text { snakes }\end{array}$} & \multicolumn{2}{|c|}{ Unknown } \\
\hline & $\mathrm{n}$ & $\%$ & $\mathrm{n}$ & $\%$ & $\mathrm{n}$ & $\%$ & $\mathrm{n}$ & $\%$ & $\mathrm{n}$ & $\%$ & $\mathrm{n}$ & $\%$ \\
\hline \multicolumn{13}{|l|}{ Severity } \\
\hline Mild & 760 & 50.4 & 84 & 45.4 & 21 & 40.4 & 4 & 66.7 & 658 & 97.8 & 403 & 67.6 \\
\hline Moderate & 468 & 31.1 & 71 & 38.4 & 11 & 21.2 & 1 & 16.7 & 8 & 1.2 & 59 & 9.9 \\
\hline Severe & 61 & 4 & 11 & 5.9 & 13 & 25 & 1 & 16.7 & 1 & 0.1 & 10 & 1.7 \\
\hline Unknown & 218 & 14.5 & 19 & 10.3 & 7 & 13.5 & 0 & 0 & 6 & 0.9 & 124 & 20.8 \\
\hline \multicolumn{13}{|l|}{ Progression } \\
\hline Cure & 1,178 & 78.2 & 146 & 78.9 & 43 & 82.7 & 5 & 83.3 & 638 & 94.8 & 461 & 77.3 \\
\hline Death & 11 & 0.7 & 0 & 0 & 0 & 0 & 0 & 0 & 0 & 0 & 2 & 0.3 \\
\hline Unknown & 318 & 21.1 & 39 & 21.1 & 9 & 17.3 & 1 & 16.7 & 35 & 5.2 & 133 & 22.3 \\
\hline Total & 1507 & 100 & 185 & 100 & 52 & 100 & 6 & 100 & 673 & 100 & 596 & 100 \\
\hline
\end{tabular}

Regarding the level of education of victims, in the majority of cases this was ignored (59.2\%). Among the 1,132 cases where education level was registered, most of the victims were illiterate or had low levels of education (29.6\%). Low levels of education may hamper the understanding of information on the biology of snakes and the risk of incidents with these reptiles. Education is fundamental to obtain knowledge regarding protection mechanisms and prevention of snakebites. Other works carried out in the country showed that accidents mainly affected individuals of lower education levels ${ }^{25,38,39}$. In relation to occupation, there was a predominance of ignored cases $(55.6 \%)$, and among cases where there was a register, the highest percentage involved rural workers (20.9\%). This finding certifies the observation carried out by Theakston et $a l .{ }^{40}$, who report that around the world, rural activities represent a risk factor in the occurrence of snakebite accidents. The higher frequency of snakebite cases among rural workers concurs with the literature ${ }^{25,33,41}$.

The majority of cases took place in rural areas. Other Brazilian series have shown rural areas as the environment with the highest incidence of these accidents, namely: D’Agostini et al. ${ }^{42}$ in Santa Catarina, Mise et al. ${ }^{43}$ in Bahia as well as Lima et $a l .^{33}$ in Amapá. This characteristic is also described in other countries as shown in studies by Dolab et $a l .{ }^{44}$ in Argentina and Mohapatra et al. ${ }^{45}$ in India. Snakebite cases are described as a tropical, rural phenomenon. In these areas, in addition to being more frequent, they also present greater severity as well as higher morbidity and mortality rates ${ }^{3}$. This increase in severity is due to the greater exposure of rural communities to risk areas and difficult access to health centers responsible for supplying antivenom. Our results show that all cases of death took place in rural areas and that the relative risk of death in these cases is 1.6 times higher than those occurring in urban and peri-urban areas. The areas of the human anatomy which suffered most from snakebites were the extremities of the limbs, that is hands and feet. This elevated incidence may be the result of the lack of protective equipment, especially in regions where there is no use of machinery in agricultural activities ${ }^{14}$. In many studies undertaken in Brazil ${ }^{26,46}$, and in the world ${ }^{4-49}$, it was reported that above all snakebites affected the extremities of the limbs.

The predominance of envenomation caused by Bothrops snakes may be a result of the large diversity of species of this genus and due to its ecological plasticity, where the snake adapts itself to environmental changes, including anthropized environments, and the fact that they are typically aggressive ${ }^{50}$. Our results also showed a considerable number of injuries caused by non-venomous snakes, higher to those caused by Crotalus, Lachesis and Micrurus. A similar study, carried out in Paraíba by Lemos et $a l .{ }^{41}$, reported that non-venomous snakes were responsible for the second highest percentage of cases. The large number of cases with non-venomous snakes in Rio Grande do Norte is probably due to their wide spatial distribution and the elevated number of species in the state. According to Puorto and França ${ }^{10}$, non-venomous snakes constitute approximately $80 \%$ of Brazil's ophidic fauna, distributing itself nationwide with over two hundred species.

The majority of victims received medical assistance between 1 and 3 hours after the accident (30.8\%), in accordance to epidemiological studies undertaken in other Northeast states of Brazil ${ }^{14,26,38}$. Victims who sought 
assistance between 3 and 6 hours presented a risk 1.7 times greater whereas the cases attended between 6 and 12 hours, 12 and 24 hours and +24 hours presented a risk 1.4, 3.8 and 1.7 times higher, respectively. These results show that the risk of death is higher in cases where victims delay medical treatment. In fact, the delay in medical care is influential in the severity of the case, in the morbidity and lethality of $\operatorname{cases}^{51,52,53}$. The late antivenom administration is a factor for bad prognosis since the venom in circulation is neutralized by the antivenom but the local lesion is not. Therefore, quick care and use of antivenom up to 3 hours after the incident increase the possibility of these cases progressing to a cure ${ }^{54}$. The majority of victims took a clotting time test $(55.5 \%)$. Among these, 962 victims showed altered values $(44.5 \%)$ and 694 victims showed normal values $(23 \%)$. Alterations in blood clotting time observed in the present study are in line with previously reported data ${ }^{32,43,55}$. According to Ribeiro et al. ${ }^{56}$, this test does not present value as a criterion of severity, however, it may be used as a parameter in the evolution of the victims' clinical status. Serotherapy is the most appropriate therapeutic resource used in snakebite cases, as well as in other injury caused by venomous animals ${ }^{57}$. Specific treatment consists in the use of antivenom and its dosage based on severity of the case. The general measures are based mainly on local care, analgesia, adequate hydration and antibiotic therapy when necessary ${ }^{9,58}$. Although the therapy with antivenom is considered a fundamental step in the management of injured people, several studies have reported the use of antivenom at doses higher or lower than those recommended by the Ministry of Health ${ }^{46,39}$. In $55.8 \%$ of cases, therapy with antivenom was applied, the Antibothropic antivenom (76.1\%) being the most used. This data is similar to those reported by Lima et al. ${ }^{24}$ and Borges et $a l .^{52}$. The Anticrotalic (8.4\%), Antibothropic-lachetic (4.1\%), Antielapidic (4.7\%) and Antibothropic-crotalic $(15.5 \%)$ antivenoms were also used although in smaller proportion. In cases of envenomation, 2,380 (78.8\%) victims showed local manifestations while 664 (21.9\%) showed systemic symptoms. The main local manifestations reported were pain $(87.9 \%)$, swelling $(64.2 \%)$, bruising $(16.2 \%)$, and paresthesia (11.2\%) (Figure 3). Similar results were described by Leite $\mathrm{et} \mathrm{al.} .^{26}$ and Oliveira et al. ${ }^{38}$ in Paraíba. The most frequent systemic symptoms were vagal (76.9\%), neuroparalytic (29.9\%), myolitic/hemolytic and renal (9.3\%) (Figure 4). These results are compatible with the systemic clinical status assigned in literature $26,32,59$.

In relation to severity, most cases were classified as mild (64\%), followed by moderate (21\%) and severe (3\%). Similar results were reported in other studies carried out in the Northeast of Brazil ${ }^{14,26,56}$. The highest number of deaths

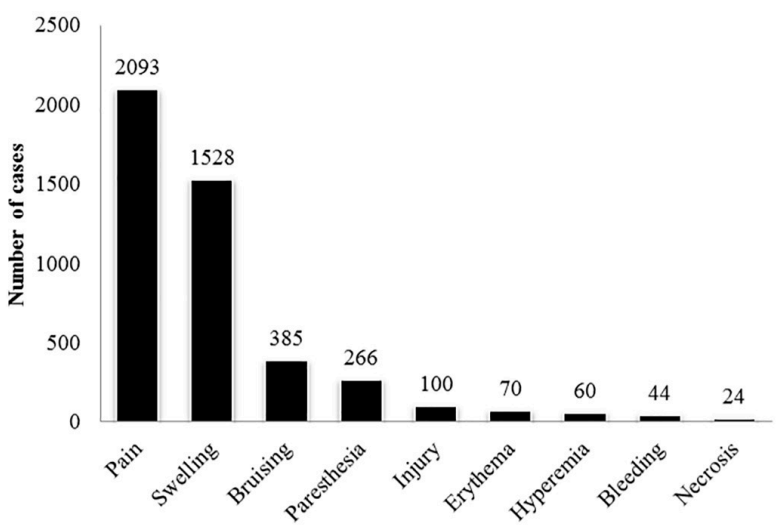

Figure 3 - Local clinical manifestations of reported cases of snakebite accidents in the state of Rio Grande do Norte, Brazil, from 2007 to 2014.

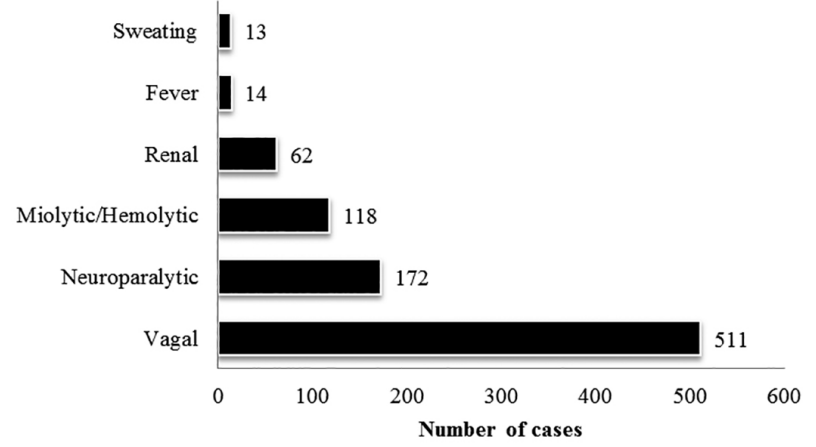

Figure 4 - Systemic clinical manifestations of reported cases of snakebite accidents in the state of Rio Grande do Norte, Brazil, from 2007 to 2014 .

took place among accidents considered severe (46.1\%). Furthermore, clinical status' considered severe presented a relative death risk 15.2 times higher when compared to those classified as mild or moderate. In envenomation caused by snakes of the Bothrops genus, there was a predominance of mild cases $(50.4 \%)$, followed by moderate $(31.0 \%)$ and severe $(4.0 \%)$. In accidents with Crotalus, mild cases $(45.4 \%)$ and moderate $(38.4 \%)$ also prevailed, with few cases classified as severe (5.9\%). In envenomation caused by the Micrurus genus, there was a predominance of mild cases $(40.4 \%)$, followed by severe $(25 \%)$ and moderate $(21.1 \%)$. In accidents with Lachesis mild cases prevailed (66.7\%), with only one moderate case (16.7\%) and one severe case $(16.7 \%)$ recorded. In studies carried out in Paraíba, Leite et al. ${ }^{26}$ and Oliveira et al. ${ }^{32}$ reported that in snakebite caused by Bothrops and Crotalus, there was a predominance of mild cases, followed by moderate and severe. In the non-venomous snakes, $97.8 \%$ were classified as mild as these animals usually only cause superficial skin wounds, without the inoculation of venom ${ }^{58}$. The results obtained from the analysis of correspondence reveal the existence of a significant association between the severity 
and the genus of the snake involved $\left(\chi^{2}=669.9 ; p<0.05\right)$. Accidents with Bothrops and Crotalus genera are more associated with moderate cases. Accidents with Lachesis are more associated with severe and moderate cases. This result is in accordance with the classification of severity established by the Ministry of Health which classifies this type of accident as moderate or severe ${ }^{58}$. Snakebites with Elapidae are more associated with severe cases. In fact, according to the Ministry of Health, envenomation by Micrurus should be considered potentially severe due to the early onset of symptoms as well as the risk of Acute Respiratory Distress Syndrome ${ }^{58}$.

The study also revealed a significant association $\left(\chi^{2}=217.7 ; p<0.05\right)$, between the area of occurrence of the snakebite and the severity of the case. Envenomation which took place in urban and peri-urban areas are more associated with clinical status' considered mild and moderate, respectively. While the cases occurring in rural areas are more associated with clinical status' classified as severe. This result may be explained by the larger interval of time that victims of rural areas take to reach the nearest health center. This shows that large time intervals between the snakebite and medical help contribute to the severity of the cases $\left(\chi^{2}=308.0 ; p<0.05\right)$. Clinical status' classified as mild are more associated to shorter time intervals, between 0 and 1 hour, 1 and 3 hours and 3 to 6 hours. On the other hand, cases considered moderate are more associated with care given over 6 hours. Severe cases are more associated with care given in 24 hours or more. These results indicate a directly proportional relation between the time of the snakebite and medical care relation, with severity.

As to the evolution of the cases, the majority led to a cure $(81.8 \%)$ and 13 deaths were recorded, among which 11 were caused by snakes of the Bothrops genus and 2 cases where the genus of the snake was unknown. The analysis of correspondence shows a significant association between the genus of the snake responsible for the accident and the evolution of the case $\left(\chi^{2}=102.7 ; p<0.05\right)$. The graphic distances in the perceptual map reveal that accidents with Bothrops are more associated with fatalities. Snakebites with Crotalus, Elapidae and Lachesis and non-venomous snakes showed a strong association with cases which evolved to a cure. Ministry of Health data assert that snakes of the Bothrops genus are responsible for the majority of accidents as well as with cases which result in death in Brazil ${ }^{58}$. In addition, a significant relation between the evolution of cases with the area of occurrence $\left(\chi^{2}=104.3 ; p<0.05\right)$ and the time elapsed from the snakebite to medical care $\left(\chi^{2}=156.7 ; p<0.05\right)$ was also observed. Our perceptual maps reveal that accidents where victims received medical care later are more associated with fatalities. This attests that lethality is intrinsically associated with late medical care, favored by the distance of rural areas to competent health centers capable of treating victims of envenomation by snake.

In conclusion, our results reveal that the epidemiological profile of snakebite cases in the state of Rio Grande do Norte is similar to those of other states in the Northeast of Brazil. The cases have ample spatial distribution and in the majority of occasions occur in rural areas during the months of higher rainfall. Furthermore, they mainly involve young men, workers and rural inhabitants of low educational levels. Snakebites affect above all the extremities of the limbs. Snakes of the Bothrops genus are responsible for the largest number of envenomation and deaths. Most victims received medical assistance within 1-3 $\mathrm{h}$ after being bitten. The majority of cases are mild in severity and evolve to a cure. Cases show mainly local manifestations (pain and swelling) and in smaller proportion, systemic manifestations (vagal). In conclusion, snakebite cases in the state of Rio Grande do Norte may be considered an issue of public health, revealing the need to develop public health policies for the prevention and reduction of snakebite cases at a local and regional level. Additionally, the training of health professionals is urgent in order to improve the registration of epidemiological information and medical care to victims.

\section{ACKNOWLEDGEMENTS}

The authors are grateful to the workers of the Health Department of the state of Rio Grande do Norte for kindly providing us with the epidemiological data.

\section{REFERENCES}

1. Gutiérrez JM, Theakston RD, Warrel DA. Confronting the neglected problem of snake bite envenoming: the need for a global partnership. PLoS Med. 2006;3:7e150.

2. Gutiérrez JM, Williams D, Fan HW, Warrell DA. Snakebite envenoming from a global perspective: towards an integrated approach. Toxicon. 2010;56:1223-35.

3. Kasturiratne A, Wickremasinghe AR, Silva N, Gunawardena NK, Pathmeswaran R, Premaratna R, et al. The global burden of snakebite: a literature analysis and modelling based on regional estimates of envenoming and deaths. PLoS Med. 2008;5:e218.

4. Bochner R, Struchiner CJ. Acidentes por animais peçonhentos e sistemas nacionais de informação. Cad Saúde Publica. 2002;18:735-46.

5. Brasil. Ministério da Saúde. Secretaria de Vigilância em Saúde. Sistema de Informação de Agravos de Notificação. Casos de ofidismo 2000-2015. Brasília: Ministério da Saúde; 2016. [cited 2016 April 7]. Available from: http://portalsaude.saude.gov.br/ 
images/pdf/2016/janeiro/20/1-Casos-Ofidismo-2000-2015.pdf

6. Brasil. Ministério da Saúde. Secretaria de Vigilância em Saúde. Sistema de Informação de Agravos de Notificação. Óbitos por ofidimos 2000-2015. Brasília: Ministério da Saúde; 2016. [cited 2016 April 7]. Available from: http://portalsaude.saude.gov.br/ images/pdf/2016/janeiro/20/3-Obitos-Ofidismo-2000-2015. pdf

7. Brasil. Ministério da Saúde. Secretaria de Vigilância em Saúde. Sistema de Informação de Agravos de Notificação. Incidência de ofidismo 2000-2015. Brasília: Ministério da Saúde; 2016. [cited 2016 April 7]. Available from: http://portalsaude. saude.gov.br/images/pdf/2016/janeiro/20/2-IncidenciaOfidismo-2000-2015.pdf

8. Fiszon JT, Bochner R. Subnotificação de acidentes por animais peçonhentos registrados pelo SINAN no estado do Rio de Janeiro no período de 2001 a 2005. Rev Bras Epidemiol. 2008;11:114-27.

9. Pinho FM, Pereira ID. Ofidismo. Rev Assoc Med Bras. 2001;47:24-9.

10. Puorto G, França FO. Serpentes não peçonhentas e aspectos clínicos dos acidentes. In: Cardoso JL, França FO, Wen FH, Maláque CM, Haddad VJ. Animais peçonhentos no Brasil: biologia, clínica e terapéutica dos acidentes. $2^{\mathrm{a}}$ ed. São Paulo: Sarvier; 2009. p.125-31.

11. Machado C, Bochner R, Friszon JT. Epidemiological profile of snakebites in Rio de Janeiro Brazil, 2001-2006. J Venom Anim Toxins Incl Trop Dis. 2012;18:217-24.

12. Instituto Brasileiro de Geografia e Estatística. Estados@: Rio Grande do Norte. Brasília: IBGE; 2010. [cited 2016 June 15]. Available from: http://www.ibge.gov.br/estadosat/perfil. php?sigla $=$ rn

13. Universidade Federal de Santa Catarina. Centro Universitário de Estudos e Pesquisas sobre Desastres. Atlas brasileiro de desastres naturais 1991 a 2010: volume Rio Grande do Norte. Florianópolis: CEPED: UFSC; 2011. [cited 2016 June 15]. Available from: http://www.mi.gov.br/ documents/10157/156218/Atlas+Rio+Grande+do+Norte.pdf/ c79f8574-da1d-401e-96dd-84e914dd8c74?version=1.0

14. Brito AC, Barbosa IR. Epidemiologia dos acidentes ofídicos no Estado do Rio Grande do Norte. ConScientiae Saúde. 2012;11:535-42.

15. Cheng Q, Xu Y, Grunsky E. Integrated spatial and spectrum method for geochemical anomaly separation. Nat Resour Res. 2000;9:43-51.

16. Otero-Patiño R. Epidemiological, clinical and therapeutic aspects of Bothrops asper bites. Toxicon. 2009;54:998-1011.

17. Rio Grande do Norte. Instituto de Desenvolvimento Sustentável e Meio Ambiente. Anuário estatístico do Rio Grande do Norte 2010. Rio Grande do Norte: IDEMA; 2010. [cited 2016 April 15]. Available from: https://drive.google.com/ file/d/0Bx0BXxMKFEmdbUlPVk1Pa3I0NDQ/edit
18. Cuenca MA, Mandarino DC. Mudanças na geografia agrícola no âmbito de microrregiões: Rio Grande do Norte, 1990 e 2004. Aracaju: Embrapa; 2007. [cited 2016 April 15]. Available from: http://www.cpatc.embrapa.br/publicacoes_2007/Doc-102.pdf

19. Serviço de Apoio às Micro e Pequenas Empresas. Diagnóstico da cadeia produtiva agroindustrial da caprinovinocultura do Rio Grande do Norte: comportamento da cadeia produtiva agroindustrial da caprinovinocultura do Rio Grande do Norte. Natal: SEBRAE; 2001.

20. Kipanyula MJ, Kimaro WH. Snakes and snakebite envenoming in Northern Tanzania: a neglected tropical health problem. J Venom Anim Toxins Incl Trop Dis. 2015;21:32.

21. Brasil. Ministério da Saúde. Secretaria de Vigilância em Saúde. Guia de vigilância epidemiológica. $6^{a}$ ed. Brasília: Ministério da Saúde; 2005. [cited 2016 April 19]. Available from: http:// bvsms.saude.gov.br/bvs/publicacoes/Guia_Vig_Epid_novo2. pdf

22. Swaroop S, Grab B. Snakebites mortality in the world. Bull World Health Organ. 1954;10:35-76.

23. Rojas CA, Gonçalves MR, Almeida-Santos SM. Epidemiologia dos acidentes ofídicos na região noroeste do estado de São Paulo, Brasil. Rev Bras Saude Prod An. 2007;8:193-204.

24. Lima JS, Martelli Jr H, Martelli DR, Silva MS, Carvalho SF, Canela JR, et al. Perfil dos acidentes ofídicos no norte do Estado de Minas Gerais. Rev Soc Bras Med Trop. 2009;42:561-4.

25. Oliveira NR, Sousa AC, Belmino JF, Furtado SS, Leite RS. The epidemiology of envenomation via snakebite in the State of Piauí, northeastern Brazil. Rev Soc Bras Med Trop. 2015;48:99-104.

26. Leite RS, Targino IT, Lopes YA, Barros RM, Vieira AA. Epidemiology of snakebite accidents in the municipalities of the State of Paraíba, Brazil. Cien Saude Colet. 2013;18:146371.

27. Albuquerque HN, Costa TB, Cavalcanti ML. Estudo dos acidentes ofídicos provocados por serpentes do gênero Bothrops notificados no Estado da Paraíba. Rev Biol Cien Terra. 2004;5:1-7.

28. Saraiva MG, Oliveira DS, Fernandes-Filho GM, Coutinho LA, Guerreiro JV. Perfil epidemiológico dos acidentes ofídicos no Estado da Paraíba, Brasil, 2005 a 2010. Epidemiol Serv Saúde. 2012;21:449-56.

29. Rahman R, Faiz MA, Selim S, Rahman B, Basher A, Jones A, et al. Annual incidence of snake bite in rural Bangladesh. PLoS Negl Trop Dis. 2010;4:e860.

30. Hansson E, Cuadra S, Oudin A, de Jong K, Stroh E, Torén K, et al. Mapping snakebite epidemiology in Nicaragua-pitfalls and possible solutions. PLoS Negl Trop Dis. 2010;4:e896.

31. Vaiyapuri S, Vaiyapuri R, Ashokan R, Ramasamy K, Nattamaisundar K, Jeyaraj A, et al. Snakebite and its socioeconomic impact on the rural population of Tamil Nadu, India. PLoS ONE. 2013;8:e80090. 
32. Oliveira HF, Barros R, Pasquino JA, Peixoto LR, Sousa JA, Leite RS. Snakebite cases in the municipalities of the State of Paraíba, Brazil. Rev Soc Bras Med Trop. 2013;46:617-24.

33. Lima AC, Campos CE, Ribeiro JR. Perfil epidemiológico de acidentes ofídicos do Estado do Amapá. Rev Soc Bras Med Trop. 2009;42:329-35.

34. Albuquerque PL, Jacinto CN, Silva Jr GB, Lima JB, Veras MS, Daher EF. Acute kidney injury caused by Crotalus and Bothrops snake venom: a review of epidemiology, clinical manifestations and treatment. Rev Soc Bras Med Trop. 2013;55:295-301.

35. Bochner R, Struchiner CJ. Aspectos ambientais e sócioeconômicos relacionados à incidência de acidentes ofídicos no Estado do Rio de Janeiro de 1990 a 1996: uma análise exploratória. Cad Saúde Pública. 2004;20:976-85.

36. Wite J. A clinicians' guide to Australian venomous bites and stings: incorporating the updated CSL antivenom handbook. Victoria: bioCSL; 2013. [cited 2017 Apr 3] Available from: http://www.toxinology.com/generic_static_files/A\%20 Clinician's\%20Guide\%20to\%20Venomous\%20Bites\%20 \&\%20Stings\%202013.pdf

37. Ávila-Aguero ML, Valverde K, Gutiérrez J, Paris MM, Faingzicht I. Venomous snakebites in children and adolescents: a 12-year retrospective review. J Venom Anim Toxins. 2001;7:69-84.

38. Oliveira FN, Brito MT, Morais IC, Fook SM, Albuquerque HN. Accidents caused by Bothrops and Bothropoides in the State of Paraiba: epidemiological and clinical aspects. Rev Soc Bras Med Trop. 2010;43:662-7.

39. Moreno E, Queiroz-Andrade M, Lira-da-Silva RM, Tavares-Neto J. Características clinicoepidemiológicas dos acidentes ofídicos em Rio Branco, Acre. Rev Soc Bras Med Trop. 2005;38:15-21.

40. Theakston RD, Warrel DA, Griffiths E. Report of a WHO workshop on the standardization and control of antivenoms. Toxicon. 2003;41:541-57.

41. Lemos JC, Almeida TD, Fook SM, Paiva AA, Simões MO. Epidemiologia dos acidentes ofídicos notificados pelo Centro de Assistência e Informação Toxicológica de Campina Grande (Ceatox-CG), Paraíba. Rev Bras Epidemiol. 2009;12:50-9.

42. D' Agostini FM, Chagas FB, Beltrame V. Epidemiologia dos acidentes por serpentes no município de Concórdia, SC no período de 2007 a 2010. Evidência. 2011;11:51-60.

43. Mise YF, Lira-da-Silva RM, Carvalho FM. Envenenamento por serpentes do gênero Bothrops no Estado da Bahia: aspectos epidemiológicos e clínicos. Rev Soc Bras Med Trop. 2007;40:569-73.

44. Dolab JA, de Roodt RA, de Titto EH, Garcia SI, Funes R, Salomon OD, et al. Epidemiology of snakebite and use of antivenom in Argentina. Trans R Soc Trop Med Hyg. 2014;108:269-76.

45. Mohapatra B, Warrell DA, Suraweera W, Bhatia P, Dhingra N, Jotkar RM, et al. Snakebite mortality in India: a nationally representative mortality survey. PLoS Neg1 Trop Dis. 2011;5e1018.

46. Bernarde PS, Gomes JO. Serpentes peçonhentas e ofidismo em Cruzeiro do Sul, Alto Juruá, Estado do Acre, Brasil. Acta Amaz. 2012;42:65-72.

47. Chippaux JP. Epidemiology of snakebites in Europe: a systematic review of the literature. Toxicon. 2012;59:86-99.

48. Spano S, Macias F, Snowden B, Vohra R. Snakebite Survivors Club: retrospective review of rattlesnake bites in Central California. Toxicon. 2013;69:38-41.

49. de Roodt AR, de Titto E, Dolab JA, Chippaux JP. Envenoming by coral snakes (Micrurus) in Argentina during the period between 1979-2003. Rev Inst Med Trop. 2013;55:13-8.

50. Lira-da-Silva RM. Bothrops leucurus Wagler, 1824 (Serpentes; Viperidae): natural history, venom and envenomation. Gaz Med Bahia. 2009;79 Supl 1:56-65.

51. França FO, Málaque CM. Acidente botrópico. In: Cardoso JL, França FO, Wen FH, Málaque CM, Haddad Jr V. Animais peçonhentos no Brasil: biologia, clínica e terapêutica dos acidentes. $2^{\text {a }}$ ed. São Paulo: Sarvier; 2009. p.81-95.

52. Borges CC, Sadahiro M, Santos MC. Aspectos epidemiológicos e clínicos dos acidentes ofídicos ocorridos nos municípios do Estado do Amazonas. Rev Soc Bras Med Trop. 1999;32:63746.

53. Ribeiro LA, Albuquerque MJ, Pires-de-Campos VA, Katz G, Takaoka NY, Lebrão ML, et al. Óbitos por serpentes peçonhentas no Estado de São Paulo: Avaliação de 43 casos, 1988/93. Rev Assoc Med Bras. 1998;44:312-8.

54. Wen FH. Soroterapia. In: Cardoso JL, França FO, Wen FH, Málaque CM, Haddad Jr V. Animais peçonhentos no Brasil: biologia, clínica e terapêutica dos acidentes. $2^{\mathrm{a}}$ ed. São Paulo: Sarvier; 2009. p. 432-45.

55. Rodrígeuz Acosta A, Uzcategui W, Azuaje R, Aguilar I, Girón ME. Análisis clínico y epidemiológico de los accidentes por mordeduras de serpientes del género Bothrops en Venezuela. Rev Cubana Med Trop. 2000;52:90-4.

56. Ribeiro LA, Jorge MT, Iverson LB. Epidemiologia dos acidentes por serpentes peçonhentas: estudos de casos atendidos em 1988. Rev Saúde Pública. 1995;29:380-8.

57. World Health Organization. Snake antivenons. Geneva: WHO; 2015 [cited 2017 Apr 3]. Available from: http://www.who.int/ mediacentre/factsheets/fs $337 / \mathrm{en} /$

58. Brasil. Ministério da Saúde. Fundação Nacional da saúde. Manual de diagnóstico e tratamento de acidentes por animais peçonhentos. $2^{\mathrm{a}}$ ed. Brasília: FUNASA; 2001. [cited 2016 April 15]. Available from: http://portalsaude.saude.gov.br/images/ pdf/2014/marco/14/Manual-de-Diagnostico-e-Tratamentode-Acidentes-por-Animais-Pe--onhentos.pdf

59. Albuquerque HN, Fernandes A, Albuquerque IC. Snakebites in Paraíba, Brazil. J Venom Anim Toxins Incl Trop Dis. 2005;11:242-51. 